\title{
THE EPISODE OF THE SLEEP OF THE DRAGON SLAYER HERO IN BYZANTINE-SLAVIC HAGIOGRAPHIC TEXTS' ${ }^{1}$
}

\author{
Matilde Casas-Olea
}

DOI: $10.17846 /$ CL.2020.13.1.16-27

\begin{abstract}
CASAS-OLEA, Matilde. The Episode of the Sleep of the Dragon Slayer Hero in Byzantine-Slavic Hagiographic Texts. One of the most widespread representations of the warrior saint in popular Byzantine-Slavic religiosity is the dragon slayer, represented by Saints Theodor and George. This image undergoes continuous resemantization and contextual adaptation, captured in creative expressions containing persistent and innovative but identifiable elements. This study analyses dragon slayer tales in the hagiographic cycles of St Theodor and St George, which feature the preamble motif of the hero's sleep. The objective was to examine the degree to which they gather the inherent narrative elements to the conventional motif and the contexts and sources in which they are shaped. It also analyses the testimony of the Christian epic, produced in popular tradition and rooted in orality.
\end{abstract}

Keywords: Dragon slayer, St Theodore Tiron, St George, hagiography, Christian epic

\begin{abstract}
Abstrakt: CASAS-OLEA, Matilde. Epizóda spiaceho hrdinu zabijaka drakov v byzantsko-slovanských hagiografických textoch. Jedno z najrozšírenejších zobrazení svätého bojovníka v ludovej byzantsko-slovanskej religiozite je zabijak drakov, zastúpený sv. Teodorom a Jurajom. Tento obraz prechádza nepretržitou resemantizáciou a kontextovým prispôsobovaním, zachyteným $\mathrm{v}$ tvorivých výrazoch obsahujúcich trvalé a inovatívne, ale identifikovatelné prvky. Táto štúdia analyzuje príbehy o zabití drakov v hagiografických cykloch sv. Teodora a sv. Juraja, ktoré uvádzajú úvodný motív hrdinovho spánku. Cielom bolo preskúmat", do akej miery zhromaždujú naratívne prvky späté s konvenčným motívom, súvislosti a zdroje, v ktorých sú formované. Analyzuje tiež svedectvo krestanského eposu, vytvorené v ludovej tradícii a zakorenené v ústnom podaní.
\end{abstract}

Klúčové slová: zabijak drakov, sv. Teodor Tyrón, sv. Juraj, hagiografia, krestanský epos

\section{Introduction}

The warrior saint is a central figure in Byzantine and Slavic Orthodox religiosity, with the image as dragon slayer prevailing over his other attributes. It reminds the universal subject of the triumph of humanity over evil, reinterpreting the victory of the martyr soldier over the pagan emperor, who is identified with the dragon in a symbolic Christian reading.

The dragon slayer myth is established in the hagiographic traditions of the two warrior saints of the état- major, St Theodor Tiron and St George. It appears in each episode that contains to greater or lesser extent the prototypical structure of the tale, identified in the index of Uther (2004) as type 300: The Dragon-Slayer. It tells of a hero who kills a dragon to rescue a maiden, often a princess. Various motifs, required for the shaping of the whole episode, are merged within this tale type and add apotropaic properties to the process of preparing and destroying the beast.

This study is part of the project FFI2015-67056, funded by the Spanish Government - FEDER. 
One of the narrative elements, typified by Hartland (1896) and included in the Motif-index of Thompson (1955), is “The Deliverer's Sleep” (D1975), which functions as a preamble to the battle with the dragon. This motif is located in epic traditions and myths from the geographic and cultural setting in which the image of the sauroctonos saint is established.

The maiden guards the hero while he sleeps. This narrative element is recorded in Thompson's Index in a series of variants with the function of introducing the magical sleep. There are varied interpretations of Motif D1962.2 "Magic sleep by delousing", possibly because this action is taboo. In Motif D1962.3, "Magic sleep by hairdressing", when the sleeper lies on the lap of someone stroking his hair, usually the maiden abducted by the dragon. This scene demonstrates the collaborative function of the maiden in the preparation for battle and her own rescue. In addition, the maiden must awake and warn the hero of the dragon's presence. She uses various means for this purpose. The topos of the hero being awakened by a tear from the maiden falling on his face appears in tales from Eastern Europe, Georgia, and Nubia (Hartland 1896-3, 211-212). In Western Europe, this motif is frequently replaced by the saint's awakening due to a mutilation, usually of a finger (Hartland 1896-3, 177).

Another motif appears in episodes that take place on the bank of a river, shore of a lake or natural spring from which the dragon emerges, ending with the hero defeating the dragon. The horse of the hero often witnesses the scene while grazing in a meadow and may even assist in the fighting.

The present study analyses the dragon slayer tales within the hagiographic cycles of St Theodor and St George and the degree to which they gather the narrative elements inherent to the motif. Accordingly, it adds the testimony of literary forms produced in popular tradition and rooted in orality to the corpus, including songs and poems identified with the Christian epic. These documents extend the field of literary motif analysis, elevating it to the category of cultural construct with the confluence of ancestral heritage indicated by the Comparatist school, while also considering evidence of intertextuality with other hagiographic sources as postulated by the Bolandist fathers ${ }^{2}$. This approach favours interpretation of the motif as a creative, cultural, and religious expression that results from the tension between persistent and innovative elements and is susceptible to continuous adaptation for specific contexts. The literary forms proposed in this study illustrate the cultural settings and motivations behind the entry into traditions of the literary motif and its persistence.

\section{Episode of the Dragon Slayer in the hagiographic tradition of St Theodor Tiron}

This episode appears in the tale of the Passio s. Theodori, recreated as a deed in the life of this warrior saint and also as the central theme of the later De dracone miracle. It is possible to reconstruct phases of motif integration and conformation within the hagiographic tale.

(1) The fight with the dragon is included in the hagiographic tale of St Theodor Tiron but not in all of its variants. This episode is not observed in the oldest manuscripts of the first redaction (Passio Prima) but soon appears in a brief interpolation in a single manuscript from 890 (Parisinus Graecus 1470):

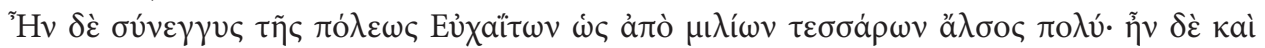
ö

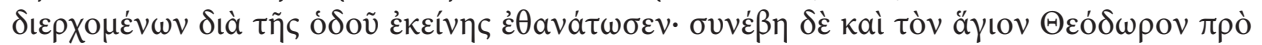

2 Also Kirpičnikov 1878, Veselovski 1880, and Matzke 1902, 1903. 


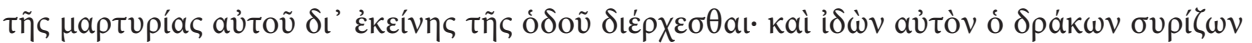

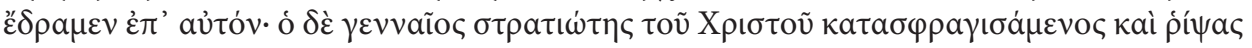

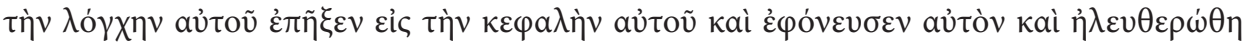

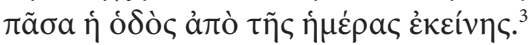

It may initially have been incorporated within the passio of the martyr in order to strengthen the bond with his homeland in Euchaita, where there was an ancestral legend about a dragon associated with a water spring ${ }^{4}$. Delehaye (AASS Nov. IV, 16) considers that the local legend may have been Christianized, attributing the defeat of the Euchaita dragon to St Theodor as patron saint of the town.

(2) Another variant of the Passio Prima, Vindobonensis Theologicus Graecus 60 (BHG 1764), dated to 934 by Delehaye (1909, 183-201; AASS Nov. IV, 49-55) but possibly based on sources from the 8th century (Walter 1999: 167), locates the extended episode in the surroundings of Euchaita, in the company of a matron of noble linage named Eusebia, who is responsible for bearing witness to the miracle (Delehaye 1909, 187-191).

(3) The Passio altera (10th c.) contains the episode of the dragon in Euchaita along with the element of the hero's sleep. The composition results from the re-telling of the tale in the 10th c. by Symeon Metaphrastes for inclusion in the menologium for February 17. The narration is conceived along the line of rhetorical Byzantine re-interpretations or metafraseis (Høgel 2014, 181-184), which are designed to lend the tale apparent veracity, although they also promote the most fantastical episodes, or to make the tale more attractive by including thaumaturgical episodes rooted in popular tradition. They contained scenes that could be recognized by the audience, whose standard references in Byzantine times were to a type of military and martyr saint observed in literary and iconographic expressions. Accordingly, the Passio altera places the episode with the dragon in Euchaita and tells of the awakening of the sleeping saint by the pious maiden Eusebia to warn him of the dragon.

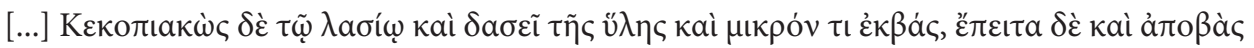

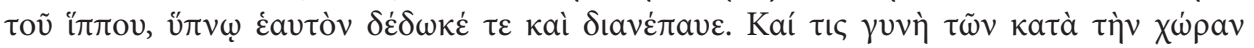

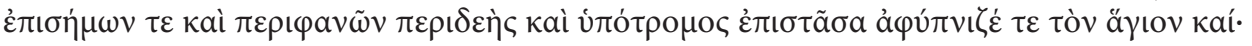

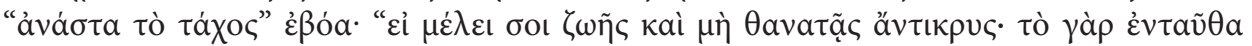

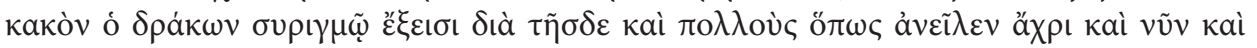

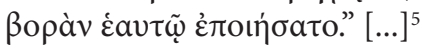

It is deduced that Metaphrastes used the first interpolated redaction as documentary source for the episode, or rather the variant in the manuscript Vindobonensis Theologicus Graecus 60; above all, however, it drew from the tale included in Acta S. Theodori Ducis by Pseudo- Abgar, which attributes the deed to another St Theodor, Stratelates ${ }^{6}$.

3 Ed. Delehaye 1909, 127.

4 The testimony is in Vita Beniamini (Amélineau 1888, 374), 7th c., which mentions the tradition related to the dragon of Euchaita as an example of the "savagery" of those in this town.

5 Ed. Delehaye 1909, 137.

6 St Theodor Stratelates is a secondary recreation, based on martyr Theodor Tiron, with the initial idea of completing and forming a pair with the recruit, but it was simultaneously established as independent literary entity from at least the 9th c., when it is first found in the hagiographic literature in a panegyric of Nicetas of Paflagonia (BHG 1753). The panegyric largely draws from the tale of Pseudo- Abgar, which must have been composed not long before (D’Aiuto 1994, 45- 51). 


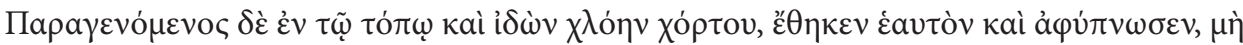

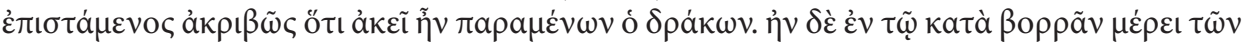

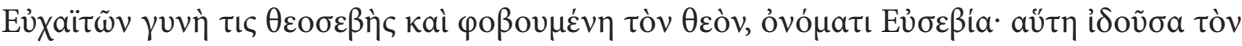

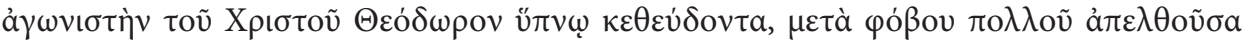

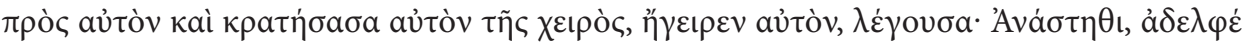

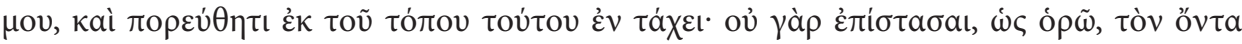

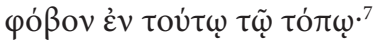

(4) The autonomous tale of the De dracone miracle appears in documents of the 14 th $c .^{8}$ It essentially describes the victory of the martyr over a dragon that blocked the supply of water to the population; however, it is closely bound to an amplification of narrative circumstances that are considerably transformed, beginning with the mythical chronotope of the tale, which places the action in the times of a mythical king Samuel (or Saul) in an unspecified city. The narrative structure of the miracle comprises two autonomous and consecutive episodes. The first narrative nucleus reproduces a deed in which the saint acts as a hero fighting the Saracen enemy, while the second tells of the rescue of his mother, who has been abducted by the dragon. Both deeds are performed while the saint is alive, unlike the other Theodorian miracles, which are posthumous. The motifs and narrative elements also differ, being more adapted to the characteristics of oral literature and folk tales than to the habitual clichés in hagiographic miracle stories.

The central episode of the dragon tale is readily identified with one of the variations of type 300, motif 300B "The king of snakes". In this variant, the king of snakes, a dragon, becomes offended and lays the country to ruin, abducting maidens. The hero is guided by a maiden who provides him with the means to defeat the snakes and therefore the dragon itself. These tales often end with the hero marrying the maiden who assists him. This "happy end" was changed in the Christian miracle of Theodor, replacing the abducted or guiding maiden with his abducted mother. To Christian eyes, the deed is motivated by filial love, although the miracle retains images from folk tales. Thus, at her first encounter with the dragon, St Theodor's mother is described as a 'lovely maiden of marriageable age and attractive appearance and very beautiful'. Subsequently, the abducted mother is represented as enthroned in the snakes' lair. The intrinsic connection of the tale with traditional literature and the characteristics of oral diffusion are evidenced in the poetical version of the miracle, which endures in the Eastern Slavic area (Bessonov 1861, No 121- 125).

\section{The episode of the Dragon Slayer in the hagiographic tradition of Saint George}

In the hagiographic cycle of St George, the Dragon Slayer episode is not included in the Passio s. Georgii but appears in an independent tale of the postmortem miracle De dracone and its derivations in the Byzantine-Slavic Christian epic. It is not related to the local cult of Lydda (Palestine) or temples where his relics were venerated, as is the case of other miracles developed in the Greek tradition ${ }^{9}$ and written between the 7th and 9th c. during confrontations between Byzantium and the Arabs in Asia Minor.

\footnotetext{
Van Hooff $1883,360-361$.

Ed. Veselovski 1879, 14-22.

$9 \quad$ Ed. Aufhauser 1913 and Festugière 1971.
} 
(1) The oldest written record of the De dracone miracle is found in the Georgian palimpsest of the Patriarchal Library of Jerusalem (Hierosolimitanus Patr. Codex 2) from the 11th century, edited by Privalova $(1977,73)$. The Greek textual tradition (BHG 687-687m) follows a tale that is very close to the Georgian palimpsest, and it is consensually acknowledged that the prototype may come from the 11 th c. ${ }^{10}$ Aufhauser $(1911,164)$ considers that the tale of the miracle of the dragon must have been orally disseminated since the 8 th $\mathrm{c}$. alongside other miracles attributed to the saint; however, it is now believed that the Greek variant may be a translation of the original Georgian tale (Walter 1995, 321). In the Slavia Orthodoxa, most of the posthumous miracles were disseminated in Southern and Eastern Slavic ecclesiastical literature before the 13th c., and the miracle of the dragon was the most widespread ${ }^{11}$.

The narratological structure of the miracle remains highly stable in the different Latin and Slavic versions, suggesting a common origin in Greek texts. It consists in a prologue and the presentation of an undefined and variable time and space framework, in which the common element is a kingdom in which sinful citizens are governed by a king with an only-begotten daughter. A dragon appears in the city as divine punishment, and the king launches an expedition to fight it but has no success. Next, the citizens meet together and hold a raffle to decide the order in which their children are to be delivered as offerings to the dragon. When the time comes to sacrifice the king's daughter, different characters bid farewell to her with lamentations, and she is abandoned alongside a river. St George appears riding a white steed on his way back from the army, and the princess tells him what has happened. The saint then offers a prayer to God before confronting and defeating the dragon. The saint hands the vanquished dragon over to the princess, who uses her sash to lead the dragon into the city, where the citizens are converted and the dragon dies. The narration closes with an account of the saint's subsequent miracles.

The confrontation with the dragon is not preceded by the sleep of the hero in any of the literary versions of the miracle.

(2) During the high Middle Ages, the legends of St George pass through new transmission pathways to reach Germanic, Anglo-Saxon, and Slavic nations in a cultural dissemination context defined by the arrival of Christianity, which brought acculturation and literacy to populations that had been virtually illiterate or highly restricted in their writing capacity. Poetic literary forms characteristic of popular tradition and rooted in orality acquire importance in this context, interacting with the patterns of written literature. This leads to the composition of the 'Christian epic', understood as a result of the permeability between written and oral literary records. The leading role is taken by St George, whose characterization is very similar to that of the epic hero.

Metric versions of the miracle of St George include a set of Greek and Balkan and Eastern Slavic variants with a certain geographic cohesion and continuity, offering evidence of a specific context for the generation and dissemination of the tale. These texts were solely preserved in oral tradition, in which they must have been conceived and transmitted when the legend was at its peak. They are composed in vernacular tongues and have narrative elements characteristic of oral literature and to a certain extent of heroic poetry, suggesting that they could be considered as Christian epics; above all, they present motifs characteristic of legends and folk tales. However, they are essentially based on the literary tales of miracula, which directly or indirectly serve as their source and share the same fundamental narratological structure.

The poems of St George and the dragon were orally transmitted and can only be studied in the written record of orally preserved verses in the 19th c., when they attracted the attention of academics. The edition by Bessonov (1861- 1864) of "Russian spiritual verses" contains five

${ }_{10}$ For the history of the Greek text, vid. Kirpičnikov 1878.

11 For the history of Slavic text, vid. Rystenko 1909. 
variants of the Russian poem on the miracle of the dragon, located in Karelia and northern Russia. In his study on popular Greek songs around St George and the dragon, Politis (1913) included records of regional variants gathered by previous authors (Cypriot variants by Sakellarios 1890 and Cretan variants by Jeannaraki 1876), while three popular Bulgarian songs are preserved in the collection of the Miladinov brothers (Zagreb, 1861).

Comparative analysis of this material reveals a shared developmental process along the same cultural continuum, which corresponds to the Byzantine area of influence, where a prototype is likely to have been composed in Greek and then transmitted to Slavs in the Balkans and old Rus in an interactive process of cultural transfer and acculturation.

\section{(2)1. The Greek poem}

The prototype Greek poem ${ }^{12}$ may have developed in a monastic setting, where miracles written in prose were known from the daily reading of synaxaria. Politis (1913, 219-220) indicates an early passage of the prose tale in 12 th c. Greek codexes into poetic form. Composers of the poetic version of the miracle may have used the prose text or rather what they remembered of it to prepare a poem in decapentasyllabic verse, disseminated in the popular Greek setting since Byzantine times. Given the circumstances of his audience and the poetic adaptation for oral declamation, the author uses compositional resources, both formal and thematic, that are characteristic of oral literature. This underscores the process of re-creating poems, shifting away from the miraculum literary model in order to integrate elements recognizable as traditional by the audience. In this way, poems of epic events or characteristic of legendary tales came to be circulated in the oral tradition. An inverse influence can also be observed, and Politis $(1913,239)$ reported that extensions of the prose miracle tale were based on poetical elements from the epic cycle on St George.

The sleep motif in the Greek poem appears after the meeting between the princess and saint beside the lake.

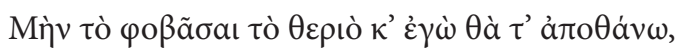

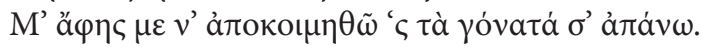

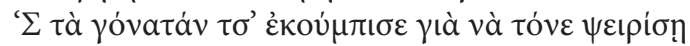

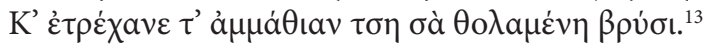

"Do not fear the beast, I will kill it,

but let me sleep on your knees."

He lay on her knees for her to delouse him,

and her eyes flowed like a dismal fountain.

\section{(2)2. The Bulgarian poem}

It is highly plausible that the Southern Slavic poems result from the oral transfer of the Greek poem in the Balkans, where it was adapted to Slavic languages and cultural referents. This was independent of knowledge of the literary tale of the miracle through translations known to have been transmitted via other pathways.

12 The variants recorded in Greek present negligible differences.

13 Jeannaraki 1876, No 1, vv. 39-42. 
Balkan Slavic poems in the cycle of St George and the dragon are not linked to the literary tale of the miracle but are strongly connected to the Greek poems, especially in relation to the motifs classified as innovative and rooted in epic tradition and orality. Although southern Slavic variants have an identifiable narration nucleus within the tradition, the narrative framework introduces specific elements that almost certainly derive from the folkloric and epic tradition of Balkan Slavs ${ }^{14}$. In addition, the formulaic style and epic octosyllables of the poem evidence the integration of the literary subject within popular southern Slavic tradition. Although decisive narrative elements in the traditional legend are omitted, there are episodes in common with the Greek tradition, such as the raffle. This supports the hypothesis of a common tradition that surpasses the text produced and disseminated in written literature and its translations, relocating the transfer of the poetic cycle within orality, in a cycle of Christian epic poems in the Balkan setting with a shared origin, possibly in Greek and in the Byzantine setting.

The sleep motif in the Bulgarian poem appears immediately after the encounter with the princess named Maria.

Ја ке легнам на твои скутови, Малу перче да ми приобидиш; Ја сум вреден тебе да откинам. Па си слезе от коњо на земи, Легна на нејдзини скутови ${ }^{15}$. $[\ldots]$ Ја догледа змиа халовита, На девојка тешко жал и падна, От жалости таја не ми скорна, Не скорна светаго Георгиа, И порона солдзи по образи; Паднаха солдзи на образо негов, Од жалости солдзи г' изгореха. И си стана свети Георгиа ${ }^{16}$.

I shall lean on your lap, so that you search in my hair a little. It saddens me to leave you". And after dismounting from his horse, he lay on the lap of the maiden.

[...]

Hala the snake saw the maiden very frightened and crestfallen, she was not woken by the dread, she did not awaken St George, but she shed tears down her face, and the tears fell on his face.

${ }_{14}$ For example, the dragon is named Hala or Lam(n)ia, both names of the female dragon-shaped demoniac creature in southern Slavic mythology.

15 Miladinov 1861, № 31, vv. 82-83 adds: кога ке излезе сурата ламиа/ на мене да кашиш "and when the pale Lamia comes out/ you cough on me".

16 Miladinov 1861, № 38, vv. 46-65. 
By the dread, the tears burned him.

And in this way St George got to his feet.

\section{(2)3. The Russian poem}

The eastern Slavic poem is known as Minor poem on Yegori the Brave (Мальй стих о Егорий Храбром). The area in which the poem was preserved is restricted to northern Russia, and the medieval testimonies related to the poem do not spread beyond this area. This allows the Minor poem to be dated with some certainty, given its evident relationship with the testimony of the frescoes of Staraia Ladoga, which reflect the legend that circulated in Novgorod towards the 12th c. (Rystenko 1909, 340-341). The Minor poem is clearly based on the literary tale (Kirpičnikov $1878,261)$ but with major extensions. All of its variants are closely related genetically; therefore, it can be assumed that a prototype was composed by an author who must have used the composition of the Slavic literary tale as its main source. Indeed, the Russian poetic variant has some elements derived from literary sources that are not yet seen in either Slavic or Greek Balkan versions. However, most of the usual deviations from the Russian poem result from the adaptation of expressive elements and thematic reinterpretations to accord with the patterns of the heroic epic. It also includes notable thematic variations. For instance, the result of the raffle means that the king must surrender himself to the beast, and he and the queen then plot to deliver the princess into the jaws of the dragon. This adds an innovative view of the subject, with the antagonistic role of the pagan monarchs and their victim, the Christian princess.

In the Russian poem, the sleep motif appears after the encounter of the princess with St George on the shore.

Тогда молодая прекрасная Лисафета

Садилась, смотрела в буйной главе пороха

У святаго Егория Храбраго,

А сама взирала очми на синее море.

Синее море разливалось;

Тогда лютый змей подымается,

Переплывает лютый змей через синее море

Ко копытечку ко ослу белому.

Тогда молодая прекрасная,

Змея лютаго испугалась,

Не посмела разбудить Егория Храбраго;

Она плакала, зело рыдала,

Обронила свою слезу святому на бело лице,

От того святой просыпается ${ }^{17}$.

Then the young and beautiful Lizafeta

sat and looked at the dust on the intrepid head

of saint Yegori the brave,

and she herself lifted her eyes to the blue sea.

The blue sea shook.

Then the ferocious snake rose,

the ferocious snake advanced through the blue sea

Bessonov No 120, vv. 137-151. 
towards the hoof of the white ass.

Then the beautiful young maiden

was frightened by the ferocious snake

and could not awaken Yegori the brave.

She cried profusely and wailed,

A tear fell on the white face of the saint

Causing the saint to awaken.

\section{Conclusions}

4.1. It can be proposed that the Dragon Slayer motif penetrates the literary tradition of St Theodor Tiron based on a local legend of Euchaita, which is Christianized with the intervention of Theodor as redeemer and Dragon Slayer. After the integration of this story, it gradually develops according to its inherent elements, with the addition of the hero's sleep (motif D1975). The character of Eusebia, who initially has the typical function of hagiographic tales to transfer and preserve the relics of the martyr in Euchaita, is recovered for the episode with the dragon. In this episode, she first serves as a nexus between Euchaita and the saint, as the mere voice of the inhabitants of the locality, and then ends up as the maiden who helps him. In secondary developments of the tale, gathered in the De Dracone miracle, the female character becomes the saint's mother, in an adaptation to Christian sensibilities of the maiden who is abducted and enthroned by the king of snakes. The assistance provided by the maiden in the episode focuses on the awakening of the saint hero while she sheds tears or holds his hand.

4.2. The episode of the hero's sleep (motif D1975) does not appear in the literary tale of the De dracone miracle of St George in any of its variants; however, it is strongly developed in the three poetical traditions described above. The episode is complemented by specific circumstances, sleeping on the riverbank of shores of a lake or sea while lying on the lap of a maiden. She guards his sleep while delousing him (motif D1962.2) or searching his head (motif D1962.3) and awakens the hero when the dragon appears, usually with a teardrop, in a variant of the topos identified by Hartland (op.cit.) and developed in Eastern Europe.

The episode of St George's sleep on the maiden's lap reveals a clear relationship of the Russian text with the Balkan tradition, developed via the traditional transmission route, i.e., Byzantium > Balkans $>$ Russia. The possibility of the original transfer taking place in the setting of written literature is remote. There is no connection between the episode and literary sources; therefore, I consider that it became consolidated in the legend of St George's via oral tradition. Thus, although the epic poems on St George and the dragon are generally based on the literary tale, all of the innovations share the incorporation of the saint's sleep and closely reproduce all of the elements identified in ancestral tradition.

4.3. It was noted above that the presence of the Dragon Slayer motif in the two cycles was interpreted by 19th c. academics as the result of intertextuality among the legends of military saints. They identified the stereotype of the dragon slayer saint with Theodor Tiron based on the greater antiquity of this motif in his hagiography, where the episode is central to the saint's life, whereas it plays clearly secondary and supplementary role in the hagiographic cycle of St George, besides being posthumous. According to this analysis, the introduction of the Dragon Slayer motif is not transferred or derived from the literary setting but rather arises analogously in both traditions due to the identification of the military saint with the cultural stereotype. The transfer exceeds the limits of written ecclesiastical literature and circulates within orality (as in the case of the Christian epic) or in oral and written records (as with the sources used in the metaphrastic 
version of Theodor). Likewise, the literary motif related to the Dragon Slayer legend appears in greater or lesser detail according to the production and diffusion setting of the literary artifact, on the degree of dependence on the stereotype, and on individual creativity. In fact, a larger number of motifs appear in the episode in St George's poems than in Saint Theodor's hagiography.

4.4. The Mythological School undoubtedly embraces one of the keys to understanding the consolidation of the Dragon Slayer stereotype, in that the pre-existence of the cult explains the dissemination of the myth and tale within a geographical area that coincides with the space in which the veneration of dragon-slaying military saints develops. The cultural expressions that manifest continuity between the pre-Christian mythological substrate and the hagiographic tradition of the dragon-slaying hero saint appear not only in the iconography of the Dragon Slayer ${ }^{18}$ but also in the original expression of the myth in epic literature, with persistent literary formulas or motifs. The hagiographic texts on St Theodor Tiron and the Christian epic of the cycle of St George include fundamental elements of the episode connected to other epic traditions in the same geographic and cultural setting. One example is the cycle of the Rostam hero in Iranian tradition, identified with the oral epic of Saka and Scythian groups. The Rostam poem includes a confrontation with a dragon that takes place after the hero has left his faithful horse to graze in a riverside meadow where he falls asleep, being awakened and assisted in the battle by his horse (Mohl 1838, 178). The key narrative foundation that may have circulated in orality for centuries before appearing in hagiographic texts can be observed in the Rostam poem. The figure of the dragon slayer also appears in the Armenian oral epic in cycles of the hero Vahagn or the king Tigranes the Great. These reproduce motifs related to the confrontation with the dragon, including the episode of the premonitory sleep, the presence of a woman on the seashore and, finally, the fight and victory of the hero over the dragon, identified with the tyrant who intends to subject his nation, a motif that is preserved in religious literature after the Christianization of Armenia. The consolidation of this motif is attributable to the intense coexistence of diverse Iranian groups with Armenians from prehistoric times, and it may have been reinforced by the strong influence of Zoroastrianism in Armenian culture (Russell 2008) ${ }^{19}$. The Mazdeist area of influence reaches the Transcaucasian region and Georgia, which preserves the tales of hero Amiran, who falls asleep before the decisive battle (Khakhanov 1892, 17). The sleeping dragon slayer motif must therefore have circulated within the oral epic of the Transcaucasian area as far as the southern coast of the Black sea in the Anatolian peninsula and Cappadocia, where the local legend of the fight with the dragon by St Theodor and later St George develops.

From the 7 th c., dissemination of the episode received a significant impulse by becoming adopted by Byzantine troops sent to Cappadocia, where mercenaries of varied origin congregated, with an intense cultural exchange. Subsequently, the legends of dragon slayer heroes and saints and their worship extended to the region of Malatya (Melitene) in the high Euphrates valley, the epicentre of the frontier of the Byzantine Empire with the Arabs, where garrisons of the Byzantine army cultivated Acritic songs that consistently feature the dragon slayer episode, including the sleep motif. One example is the poem of Digenis Akrites, whose pre-battle sleep is guarded by his beloved, who then awakes him when a three-headed dragon appears beside a natural spring. ${ }^{20}$

On the other side of the frontier, the Arabs also developed their own local epic romances on dragon slayer heroes that may have originated in the 7th c (Pancaroğlu 2004, 157).

\footnotetext{
18 After appearing in Iranian imperial imagery, the narrative then arises in Greco-Roman civilization, being used by Constantine the Great as a symbol of victory of the Roman Empire (vid. Eus., VC, 3. 3).

19 It is sufficient to note the relationship with the Armenian term for dragon slayer, vishapakiat, which corresponds to a calque of Avestan varəAra-jan- and Vedic vrtra-hán-.

20 Ed. Jeffreys 1998, 154- 156.
} 
Accordingly, inclusion of the dragon slayer in the hagiographic traditions of the military saints Theodor and George is attributable to the epic context in which the stereotype of dragon-slayer hero is defined, in which the pre-battle sleep is a consistent element. A direct influence of the motif in tales of St Theodor on the poetical derivations of St George is more controversial. This because of the existing popularity of the motif in orality, in both the epic and other genres of popular literature, especially the specific elements of the episode in the poetical tale of St George, suggesting an independent composition of the tale of Theodor, although within the same setting.

\section{REFERENCES}

Acta Sanctorum Socii J. Bollandi (abbreviated to AASS), 71 vols., Paris, 1863-1940.

Amélineau, Émile. 1888. Fragments coptes pour servir à l'histoire de la conquête de l'Égypte par les Arabes. In Journal Asiatique 12, 8-12.

Aufhauser, Joannes. 1911. Das Drachenwunder des Heiligen Georg in der griechischen und lateinischen Überlieferung. Leipzig.

Aufhauser, Joannes. 1913. Miracula S. Georgii. Leipzig.

Bessonov, Petr Alekseevič. 1861. Калики перехожие. Сборник стихов и исследования [Itinerant cripples. A collection of verses and study], Moscow.

D’Aiuto, Francesco. 1994. Tre canoni di Giovanni Mauropode in onore di santi militari. Roma.

Delehaye, Hippolyte. 1909. Les Légendes Grecques des Saints Militaires. Paris.

Festugière, André-Jean. 1971. Collection grecques de miracles: Sainte Thècle, Saints Côme et Damien, Saints Cyr et Jean (extraits), Saint Georges. Paris.

Halkin, François. 1957. Bibliotheca Hagiographica Graeca (abbreviated to BHG). Bruxelles.

Hartland, Edwin S. 1896. The Legend of Perseus: A Study of Tradition in Story, Custom and Belief. London.

Høgel, Christian. 2014. Symeon Metaphrastes and the Metaphrastic Movement. In Efthymiadis, S. (ed.). The Ashgate Research Companion to Byzantine Hagiography. Vol.2: Genres and Contexts. Franham- Burlington, 181-196.

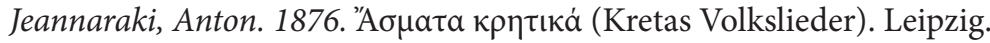

Jeffreys, Elisabeth. 1998. Digenis Akritis. The Grottaferrata and Escorial Versions. Cambridge.

Khakhanov, Aleksandr Solomonovič. 1892. Грузинский извод сказания о св. Георгии [Georgian versión of the Legend of St. George]. Moscow.

Kirpičnikov, Aleksandr Ivanovič. 1878. Святой Георгий и Егорий Храбрый [St George and Egorij the Brave]. In Журнал Министерства Народнаго Просвещенния 2, 268-327.

Matzke, John E. 1902. Contributions to the History of the Legend of Saint George, with Special Reference to the Sources of the French, German and Anglo-Saxon Metrical Versions. In Modern Language Association 17 (4), 464-535.

Matzke, John E. 1903. Contributions to the History of the Legend of Saint George, with Special Reference to the Sources of the French, German and Anglo-Saxon Metrical Versions. In Modern Language Association 18 (1), 99-171.

Miladinovi, Dimitr and Konstantin. 1861. Бљлгарски народни пъсни [Bulgarian Folk Songs]. Zagreb.

Mohl, Julius. 1838. Ferdowsī. Šāh-nāma. Le livre des rois. Paris.

Pancaroğlu, Oya. 2004. The Itinerant Dragon-Slayer: Forging Paths of Image and Identit in Medieval Anatolia. In Gesta 43 /2, 151-164.

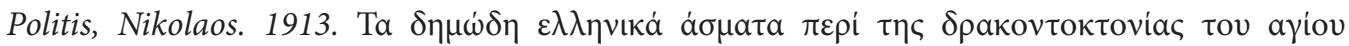

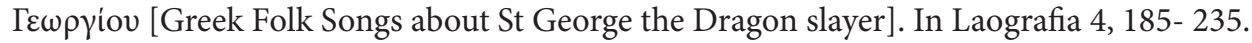


Privalova, Eka. 1977. Павниси [Pavnisi]. Tbilisi.

Russell, James R. 2008. Magic Mountains, Milky Seas, Dragon Slayers, and other Zoroastrian Archetypes. In Bulletin of the Asia Institute 22, 57-77.

Rystenko, Aleksandr Basilevič. 1909. Легенда о св. Георгии и драконе [Legend of St George and the Dragon]. Odessa.

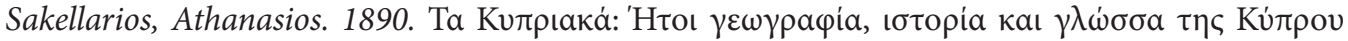

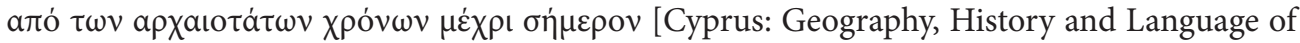
Cyprus from ancient times to the present day]. Athens.

Uther, Hans-Jörg. 2004. The Types of International Folktales: A Classification and Bibliography based on the system of Antti Aarne and Stith Thompson. Helsinki.

Van Hooff, Willen. 1883. Acta graeca S. Theodori ducis. In Analecta Bollandiana 2, 359-367.

Veselovskij, Aleksandr Nikolaevič. 1879. Греческий апокрифъ о св. Өеодоръ [Greek Apocrypha of St Theodor]. Разыскания в области русских духовных стихов [Investigations on Russian Spiritual Verses]. Saint Petersburg.

Veselovskij, Aleksandr Nikolaevič. 1880. Св. Георгий в легенде, песне и обряде [St George in legend, songs and cult]. Разыскания в области русских духовных стихов [Investigations on Russian Spiritual Verses]. Saint Petersburg.

Walter, Christopher. 1995. The Origins of the Cult of St. George. In Revue des Études Byzantines 53, 295-326.

Walter, Christopher. 1999. Theodore, archetype of the warrior saint. In Revue des Études Byzantines 57, 163-210.

SUMMARY: THE EPISODE OF THE SLEEP OF THE DRAGON SLAYER HERO IN BYZANTINE-SLAVIC HAGIOGRAPHIC TEXTS. The Dragon-Slayer myth appears in the hagiographic traditions of warrior saints Theodor Tiron and George in episodes that include the prototypic structure of the tale. One of the narrative elements of the episode is “The Deliverer's Sleep", which includes the motifs of "Magic sleep by delousing" or "Magic sleep by hairdressing". There is also the characteristic presence of an abducted maiden who collaborates with the hero by awakening him and warning of the danger. In the hagiography of St Theodor, this episode appears as an interpolation based on a local legend in Euchaita and is subsequently extended by interaction with traditional and oral literature. The cycle of St George includes the episode in the Christian epic variants founded on the autonomous tale of the De dracone miracle. The presence of the episode in both cycles is a consequence of the interaction of oral tradition with hagiographic literature in a specific geographic setting over a given time period.

Associate Professor Matilde Casas-Olea, Ph.D

University of Granada

Department of Greek and Slavic Philology

Campus de Cartuja s/n

18011 Granada

Spain

mcasas@ugr.es 